Supporting Information

\title{
A Small Molecule That Represses Translation of G- Quadruplex-Containing mRNA
}

\author{
Yousuke Katsuda $^{\dagger}$, Shin-ichi Sato ${ }^{\dagger *}$, Lisa Asano ${ }^{\dagger \dagger}$, Yoshitaka Morimura $^{\S}$, \\ Tomoyuki Furuta $^{\dagger}$, Hi-roshi Sugiyama ${ }^{\dagger \|}$, Masaki Hagihara ${ }^{\perp *}$, \\ and Motonari Uesugi ${ }^{\dagger * *}$
}

${ }^{\dagger}$ Institute for Integrated Cell-Material Sciences (WPI-iCeMS) and

$¥$ Institute for Chemical Research, Kyoto University, Uji, Kyoto 611-0011, Japan

${ }^{\S}$ Center for the Promotion of Excellence in Higher Education, Kyoto University, Kyoto 606-8501, Japan

"Department of Chemistry, Graduate School of Science, Kyoto University, Kyoto 6068502, Japan.

${ }^{\perp}$ Graduate School of Science and Technology, Hirosaki University, Hirosaki, Aomori 036-8561, Japan

*E-mail: ssato@ scl.kyoto-u.ac.jp (S.S.), hagihara@ @irosaki-u.ac.jp (M.H.) or uesugi@scl.kyoto-u.ac.jp (M.U.) 


\section{Supplementary Contents}

Supplementary Notes

Supplementary Material

Supplementary Methods

Supplementary Figures

$\begin{array}{ll}\text { Figure S1. } & \text { S11 }\end{array}$

$\begin{array}{ll}\text { Figure S2. } & \text { S12 }\end{array}$

$\begin{array}{ll}\text { Figure S3. } & \text { S13 }\end{array}$

$\begin{array}{lr}\text { Figure S4. S14 } & \text { S13 }\end{array}$

$\begin{array}{lr}\text { Figure S5. } & \text { S15 }\end{array}$

$\begin{array}{lr}\text { Figure S6. } & \text { S16 }\end{array}$

$\begin{array}{lr}\text { Figure S7. } & \text { S17 }\end{array}$

$\begin{array}{lr}\text { Figure S8. } & \text { S18 }\end{array}$

$\begin{array}{lr}\text { Figure S9. } & \text { S19 }\end{array}$

$\begin{array}{lr}\text { Figure S10. } & \text { S20 }\end{array}$

Supplementary Tables

$\begin{array}{lr}\text { Table S1. } & \text { S21 }\end{array}$

$\begin{array}{lr}\text { Table S2. } & \text { S22 }\end{array}$ 


\section{Supplementary Note}

\section{Chemical synthesis of molecule 1 (RGB-1)}
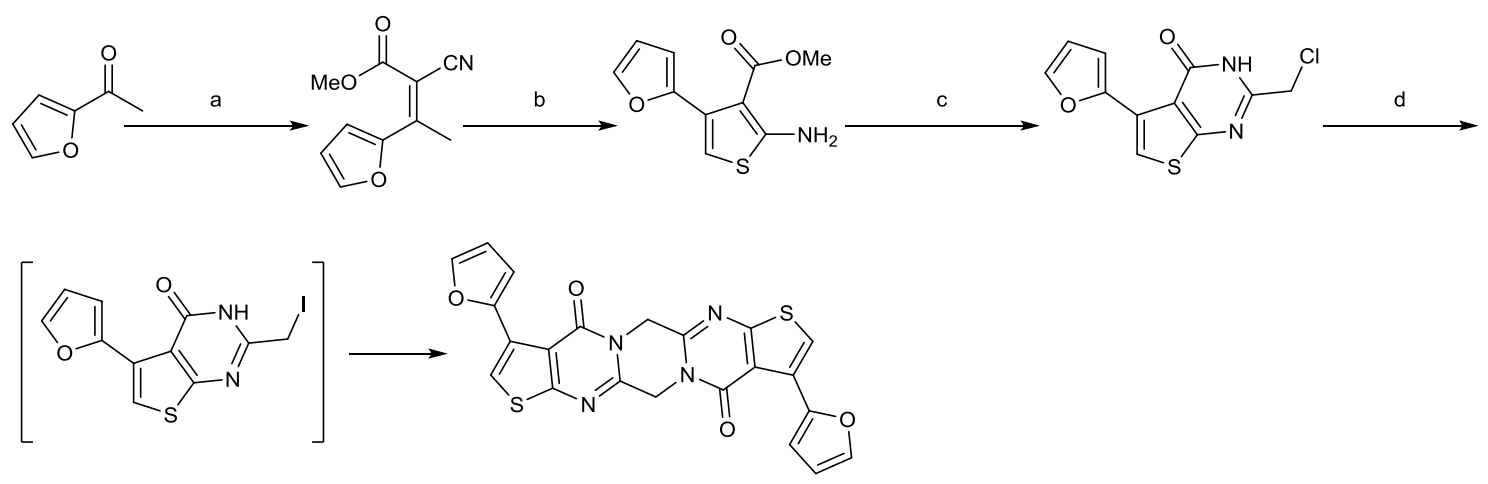

Reagent and conditions: a) methyl cyanoacetate, $\mathrm{NH}_{4} \mathrm{OAc}, \mathrm{AcOH}$, toluene, 28.7\%; b) sulfur, morpholine, EtOH, 5\%; c) Chloroacetonitrile, 4N HCl/dioxane, 94\%; d1) NaI, acetone; d2) $\mathrm{K}_{2} \mathrm{CO}_{3}$, acetone, $14 \%$.<smiles>COC(=O)C(C#N)=C(C)c1ccco1</smiles>

Molecule 3: methyl (2E,Z)-2-cyano-3-(furan-2-yl)but-2-enoate. Methyl cyanoacetate $(11.7 \mu \mathrm{L})$ and ammonium acetate $(1862 \mathrm{mg})$ were added to a solution of 2-acetylfurane $(13 \mathrm{~g})$ in toluene $(224 \mu \mathrm{L})$ and $\mathrm{AcOH}(5447 \mu \mathrm{L})$, and the mixture was heated to reflux. After stirring for $13 \mathrm{~h}$, the reaction mixture was cooled to room temperature and quenched with water. The crude mixture was extracted with EtOAC (50 $\mathrm{mL} \times 3$ ), and the combined organic layers were washed with brine, dried over $\mathrm{MgSO}$, and concentrated in vасио. Purification by flash chromatography, with silica gel and ethyl acetate/n-hexane $(7: 93 \sim 55: 45)$ as eluent, gave molecule 3 (28.7\%) . ${ }^{1} \mathrm{H}-\mathrm{NMR}\left(300 \mathrm{MHz}, \mathrm{CDCl}_{3}\right) \delta: 7.69(1 \mathrm{H}, \mathrm{dd}, J=1.8,0.7 \mathrm{~Hz}), 7.57(1 \mathrm{H}$, d, $J=3.7 \mathrm{~Hz}), 6.63(1 \mathrm{H}, \mathrm{dd}, J=3.7,1.8 \mathrm{~Hz}), 3.87(3 \mathrm{H}, \mathrm{s}), 2.71(3 \mathrm{H}, \mathrm{s}) .{ }^{13} \mathrm{C}-\mathrm{NMR}\left(75 \mathrm{MHz}, \mathrm{CDCl}_{3}\right) \delta$ : $163.36,154.71,150.89,146.55,120.84,118.90,117.29,113.25,52.60,17.40$. MS (EI) calculated for $\mathrm{C}_{10} \mathrm{H}_{9} \mathrm{NO}_{3}[\mathrm{M}]^{+}: 191.0582$ was 191.0584 . 


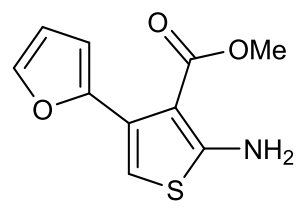

Molecule 4: methyl 2-amino-4-(2-furyl)thiophene-3-carboxylate. Sulfur (250 mg) and morpholine (2.1 $\mathrm{ml}$ ) were added to a solution of molecule $2(1 \mathrm{~g})$ in $\mathrm{EtOH}(695 \mu \mathrm{L})$, and the mixture was heated to reflux. After stirring for $3 \mathrm{~h}$, the mixture was filtered through a short pad of silica gel, followed by washing with ethyl acetate. The combined filtrate was washed twice with water, dried over sodium sulphate, and concentrated in vасио. The crude material was purified over silica gel, using ethyl acetate/n-hexane (7:93 55:45) as eluent, to give molecule $4(5 \%) .{ }^{1} \mathrm{H}-\mathrm{NMR}\left(300 \mathrm{MHz}, \mathrm{CDCl}_{3}\right) \delta: 7.41(1 \mathrm{H}, \mathrm{dd}, J=1.9,0.8 \mathrm{~Hz})$, $6.48(1 \mathrm{H}, \mathrm{d}, J=3.3 \mathrm{~Hz}), 6.44-6.38(2 \mathrm{H}, \mathrm{m}), 6.15-5.98(2 \mathrm{H}, \mathrm{m}) .{ }^{13} \mathrm{C}-\mathrm{NMR}\left(75 \mathrm{MHz}, \mathrm{CDCl}_{3}\right) \delta: 165.62$, $163.83,150.09,141.36,130.06,120.86,110.70,107.99,106.92,50.89$. MS (FAB) calculated for $\mathrm{C}_{10} \mathrm{H}_{9} \mathrm{NO}_{3} \mathrm{~S}[\mathrm{M}]^{+}: 223.0303$ was 223.0305 .

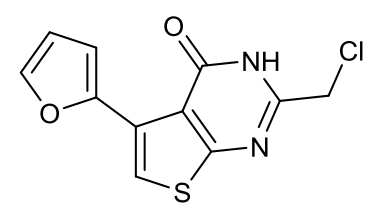

Molecule 5: 2-(chloromethyl)-5-(furan-2-yl)-3H-thieno[2,3-d]pyrimidin-4-one. Molecule 4 (200 mg) and chloroacetonitrile $(73 \mu \mathrm{L})$ were combined in $4 \mathrm{~N} \mathrm{HCl}$ in dioxane. After stirring for $3 \mathrm{~h}$, the reaction mixture was concentrated in vacuo. The residue was added to $5 \%$ aq. $\mathrm{NH}_{3}$, and a white solid was formed. The solid was collected by filtration and washed with water $(0.5 \mathrm{~mL} \times 2)$ and diethyl ether $(0.5 \mathrm{~mL} \times 2)$. The residue was dried under reduced pressure to give molecule $5(223 \mathrm{mg}, 94 \%)$. ${ }^{1} \mathrm{H}-\mathrm{NMR}\left(\mathrm{CDCl}_{3}\right) \delta: 11.65$ $11.34(1 \mathrm{H}, \mathrm{m}), 7.63(1 \mathrm{H}, \mathrm{d}, J=3.3 \mathrm{~Hz}), 7.59(1 \mathrm{H}, \mathrm{s}), 7.47(1 \mathrm{H}, \mathrm{d}, J=1.8 \mathrm{~Hz}), 6.51(1 \mathrm{H}, \mathrm{dd}, J=3.4,1.8$ $\mathrm{Hz}), 4.60(2 \mathrm{H}, \mathrm{s}) .{ }^{13} \mathrm{C}-\mathrm{NMR}$ (75 MHz, DMSO-D $) \delta: 157.91,153.35,148.30,142.88,127.42,120.47$, 118.42, 111.66, 110.59, 99.63, 42.27. MS (FAB) calculated for $\mathrm{C}_{11} \mathrm{H}_{7} \mathrm{ClN}_{2} \mathrm{O}_{2} \mathrm{~S}[\mathrm{M}+\mathrm{H}]^{+}: 266.9995$ was 226.9995 . 


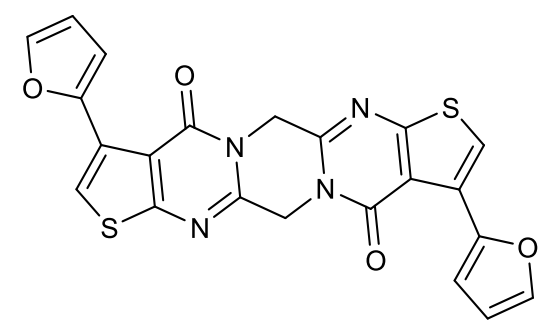

\section{Molecule 1 (RGB-1): 8,18-bis(furan-2-yl)-6,16-dithia-1,4,11,14-tetraazapentacyclo}

[11.7.0.0 $\left.{ }^{3}{ }^{11} .0^{5},{ }^{9} .0^{15},{ }^{19}\right]$ icos-3,5 (9),7,13,15(19),17-hexane-10,20-dione. NaI (25 mg) was added to a solution of molecule $5(30 \mathrm{mg})$ in acetone $(1 \mathrm{~mL})$, and the mixture was heated to reflux. After stirring for $30 \mathrm{~min}$, the reaction mixture was cooled to $40{ }^{\circ} \mathrm{C}$ and $\mathrm{K}_{2} \mathrm{CO}_{3}(62 \mathrm{mg})$ was added. After stirring for $3 \mathrm{~h}$, the resulting mixture was cooled to room temperature, followed by quenching with water $(1 \mathrm{~mL})$, and the white solid that formed was collected by filtration. The solid was suspended in hot EtOAc $(1 \mathrm{~mL})$, collected by filtration, and dried at reduced pressure to give molecule $\mathbf{1}$ (7.2 $\mathrm{mg}, 14 \%)$. ${ }^{1} \mathrm{H}-\mathrm{NMR}(300$

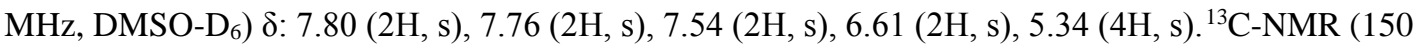
MHz, DMSO-D 6 ) $\delta: 164.52,155.73,150.47,148.10,142.89,127.39,118.62,117.26,111.60$, 110.38,44.23. MS (EI) calculated for C22H12N4O4S2 [M] $]^{+}: 460.0300$ was 460.0301.
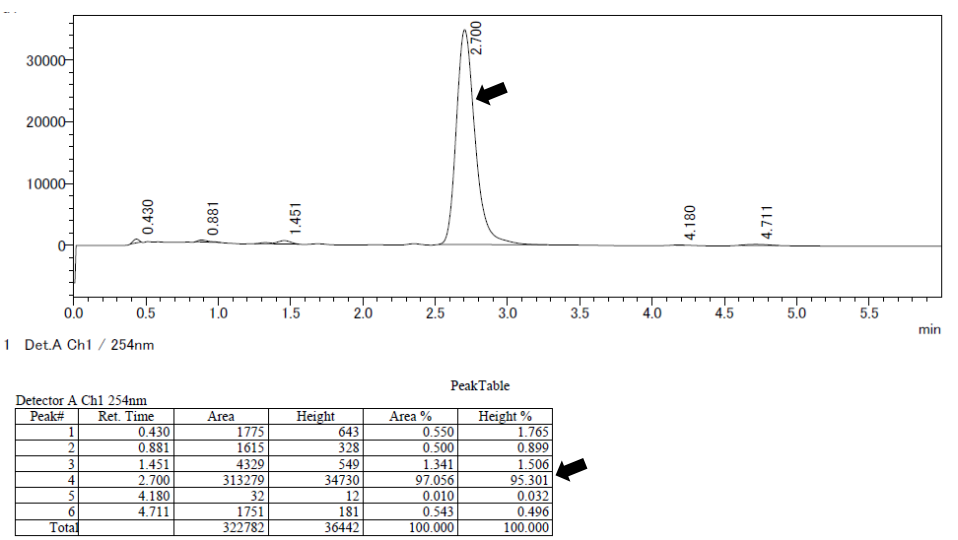

\section{Supplementary Material}

The chemical library compound. The 8000 compounds used in the study follow the drug-like rules of Lipinski and Veber and have diversity in chemical structures selected from our collection of $\sim 70,000$ molecules.

Oligonucleotides. The oligonucleotides were purchased from Thermo Fisher Scientific, Inc. All the samples except for the evaluation of $K_{\mathrm{d}}$ and $T_{\mathrm{m}}$ values were desalted grade. HPLC-purified oligonucleotides were used for determination of $K_{\mathrm{d}}$ and $T_{\mathrm{m}}$ values. 


\section{Supplementary Methods}

RTase reaction-based chemical screening. RNAs for chemical screening were prepared by in vitro transcription reaction at $37^{\circ} \mathrm{C}$ for $12 \mathrm{~h}$ using T7 MegaScript kit (Ambion ${ }^{\circledR}$ ). The DNA templates for in vitro transcription were designed and purchased from GenScript as pET28a plasmids (Supplementary Table 1). The linear dsDNA was amplified by PCR from the pET28a plasmids with forward primer [5'-TAA TAC GAC TCA CTA TAG GGC AGC AGC CAT CAT CAT C-3'] and reverse primer [5'-CTC AGC GGT GGC AGC AGC CAA CTC-3']. The PCR products were separated and purified by $8 \%$ polyacrylamide gel electrophoresis (PAGE), followed by gel elution. RNAs were transcribed from the dsDNA templates using T7 RNA polymerase, and purified using an NAP-5 column to remove unincorporated NTPs. The purified template RNA $(100 \mathrm{nM})$ was heated to $85^{\circ} \mathrm{C}$ for $3 \mathrm{~min}$, then cooled to ambient temperature to allow Gquadruplex formation. A reaction mixture of the template RNA $(10 \mathrm{nM})$ and a chemical compound (10 $\mu \mathrm{M}$ ) was incubated for $10 \mathrm{~min}$ at ambient temperature. ReverTra Ace reverse transcriptase (TOYOBO), RT primer [5'-CTC AGC GGT GGC AGC AGC CAA CTC-3'], $\mathrm{MgCl}_{2}$, and dNTPs were added to the reaction mixture, and the reaction was carried out at $37^{\circ} \mathrm{C}$ for $15 \mathrm{~min}$. The reaction product $(1 \mu \mathrm{L})$ was used as a template for quantitative PCR (qPCR). The primers for qPCR were designed as forward primer [5'-GGG CAG CAG CCA TCA TCA TC-3'] and reverse primer [5'-CTC AGC GGT GGC AGC AGC CAA CTC3']. qPCR analysis was performed on an ABI 7500HT sequence detection system (Applied Biosystems) with $\mathrm{SYBR} \otimes$ Green. $\triangle \mathrm{Ct}$ values were estimated by subtracting the $\mathrm{Ct}$ value of $\mathrm{qPCR}$ with a compound from the $\mathrm{Ct}$ value of qPCR without the compound.

Melting temperature $\left(\boldsymbol{T}_{\boldsymbol{m}}\right)$. Melting temperature of G-quadruplexes was measured by monitoring circular dichroism (CD) spectra. The CD melting experiments were performed on a J-725 (JASCO) CD spectrophotometer equipped with a Peltier temperature controller. The spectra were recorded from 220 to $340 \mathrm{~nm}$ with a scanning speed of $200 \mathrm{~nm} / \mathrm{s}$. Temperature scans were performed for RNA G-quadruplexes $(2.5 \mu \mathrm{M})$ with or without G-quadruplex stabilizers $(5 \mu \mathrm{M})$ by scanning continuously from 40 to $90^{\circ} \mathrm{C}$ at $265 \mathrm{~nm}$ in $10 \mathrm{mM}$ Tris- $\mathrm{HCl}$ buffer (pH 7.6) containing $100 \mathrm{mM} \mathrm{KCl} . T_{m}$ of duplex and hairpin stem RNAs was measured by UV melting experiments on a JASCO V-650 UV/VIS, as previously described ${ }^{11}$. Temperature scans were performed for G-quadruplexes $(5 \mu \mathrm{M})$ with or without G-quadruplex stabilizers by scanning continuously from 40 to $95^{\circ} \mathrm{C}$ at $265 \mathrm{~nm}$ in $10 \mathrm{mM}$ Tris- $\mathrm{HCl}$ buffer (pH 7.6) containing 100 $\mathrm{mM} \mathrm{KCl} . T_{m}$ was determined as the temperature at half of the maximum signal decrease. Oligonucleotides for $T_{m}$ measurements were purchased from Thermo Fisher Scientific, Inc. (Supplementary Table 1). Prior to use, samples were heated to $90^{\circ} \mathrm{C}$ for $5 \mathrm{~min}$ and gradually cooled to room temperature for $30 \mathrm{~min}$ in the above buffer. 
Kd determination. Oligonucleotides were purchased from Thermo Fisher Scientific, Inc. (Supplementary Table 1). RGB-1 was incubated in binding buffer (10 mM Tris- $\mathrm{HCl}(\mathrm{pH} \mathrm{7.6)}$ containing $100 \mathrm{mM} \mathrm{KCl})$ at $4^{\circ} \mathrm{C}$ in the presence of oligonucleotides $(0,0.1,0.3,1,3,10,30$, or $100 \mu \mathrm{M})$. After a 30-minute incubation, the reaction mixture was separated by gel filtration using illustra ${ }^{\mathrm{TM}} \operatorname{MicroSpin}^{\mathrm{TM}} \mathrm{G}-25$ columns. The flowthrough fraction was collected and treated with RNase A or DNase to degrade oligonucleotides. The fraction was then subjected to HPLC to quantify RGB-1. The percent of RGB-1 bound to oligonucleotide was calculated as 100(AbsT - AbsF)/AbsT, where AbsT is peak area of RGB-1 in HPLC analysis at 280 $\mathrm{nm}$ before gel filtration, and $\mathrm{AbsF}$ is peak area of RGB-1 in the flow-through fraction at $280 \mathrm{~nm}$ after gel filtration. HPLC analyses were normalized to the peak area of theophylline, co-injected as an internal standard. The $K_{\mathrm{d}}$ values of RGB-1 and TERRA were estimated from saturation curves by nonlinear leastsquares analysis, using the following binding equation:

Fobs $=A\left(\left(\left([\text { RGB }-1]_{\mathrm{T}}+[\text { TERRA }]_{\mathrm{T}}+K_{\mathrm{d}}\right)-\left(\left([\mathrm{RGB}-1]_{\mathrm{T}}+[\text { TERRA }]_{\mathrm{T}}+K_{\mathrm{d}}\right)^{2}-4[\text { RGB- }-1]_{\mathrm{T}}[\mathrm{TERRA}]_{\mathrm{T}}\right) 1 / 2\right) /\right.$ $\left.2[\mathrm{RGB}-1]_{\mathrm{T}}\right)$

where $A$ is the relative peak area of RGB-1, $K_{\mathrm{d}}$ is the dissociation constant, and $[\mathrm{RGB}-1]_{\mathrm{T}}$ and $[\text { TERRA }]_{\mathrm{T}}$ are the total concentrations of RGB-1 and TERRA, respectively.

Preparation of the NRAS 5'UTR and Reverse Transcriptase (RTase) Stop Assay. The human NRAS 5'UTR fragment (wild-type) was amplified by PCR from genomic DNA (Novagen) with a specific primer set (5'-TAA TAC GAC TCA CTA TAG AAA CGT CCC GTG TGG GAG GGG CGG GT-3' and 5'-TCC AAC TAT GTA TAC CTG TTC ACA CCA GCA AGA ACC TCA AGC TCC A-3'), and cloned into pMD19 vector. The GGG-to-AAA mutant of NRAS 5'UTR (mut1) was prepared using a QuickChange site-directed mutagenesis kit (Stratagene) according to the manufacturer's protocol. dsDNAs for RNA transcription were prepared from oligonucleotides by PCR-amplification with a T7 promoter primer [5'-TAA TAC GAC TCA CTA TAG AA-3'] and a 3'-DNA primer [5'-TCC AAC TAT GTA TAC CTG-3']. Resulting dsDNAs were transcribed to ssRNA using an AmpliScribe T7 Transcription Kit (Epicentre). RNAs were purified with 8\% polyacrylamide gel containing $6 \mathrm{M}$ urea. A reaction mixture of template RNA $(0.3 \mu \mathrm{M})$ and 5'-Texas Redlabeled 3'-DNA primer $(0.1 \mu \mathrm{M})$ was heated to $80^{\circ} \mathrm{C}$ for $3 \mathrm{~min}$ and cooled to ambient temperature. ReverTra Ace reverse transcriptase (TOYOBO), $\mathrm{MgCl}_{2}$, and dNTPs were then added to the reaction mixture, and the reaction was carried out for $30 \mathrm{~min}$. The reaction products were purified and analyzed on a Hitachi SQ5500E automated sequencer. The sequencing markers were prepared with the SequiTherm EXCEL II DNA Sequencing Kit (Epicentre), using double template DNAs as templates.

In vitro translation from mRNA containing NRAS 5'UTR. The dsDNA for firefly luciferase (FL) were amplified by PCR using psiCHECK-2 (Promega) vector as a template, with a forward primer [5' -GCT GGT GTG AAA TGG CCG ATG CTA AGA ACA TTA AGA AGG GCC C -3’'], and reverse primer [5' - CGC 
GTG AAT TCT CGA TTA CAC GGC GAT CTT GCC-3']. The dsDNAs for NRAS 5'UTR (wild-type) and its mutant (mut1) were amplified by PCR using the pMD19-NRAS-UTR constructs as templates, with a forward primer [5'- ATA GGC TAG CCT CGA GAA ACG TCC CGT GT-3'] and reverse primer [5'GCA TCG GCC ATT TCA CAC CAG CAA GAA CC-3']. Other mutants of NRAS 5'UTR (mut2 and mut3) were prepared by overlap extension PCR, using the pMD19-NRAS UTR constructs as templates. Two DNA fragments of mut2 or mut3 were amplified by PCR, using the pMD19-NRAS UTR wild-type or mut1 construct, with a forward primer [5'- ATA GGC TAG CCT CGA GAA ACG TCC CGT GT-3'] and reverse primer [5'-TTT TGC CCG CTA CGT AAT CAG TCG GC-3'], or forward primer [5'- GAT TAC GTA GCG GGC AAA ACC GGA AG-3'] and reverse primer [5'-CGC GTG AAT TCT CGA TTA CAC GGC GAT CTT GCC-3']. To obtain mut2 and mut3, each set of PCR products was connected by overlap extension PCR, using a forward primer [5'- ATA GGC TAG CCT CGA GAA ACG TCC CGT GT-3'] and reverse primer [5'-CGC GTG AAT TCT CGA TTA CAC GGC GAT CTT GCC-3']. The PCR products for NRAS 5'UTR (wild-type, mut1, mut2, and mut3) and FL were connected by overlap extension PCR using a forward primer [5'- ATA GGC TAG CCT CGA GAA ACG TCC CGT GT-3'] and reverse primer [5'-CGC GTG AAT TCT CGA TTA CAC GGC GAT CTT GCC GCC TTT C-3']. Each PCR product was subcloned into the Xho I site in pIRES vector (Clontech Laboratories, Inc.). The linear dsDNA templates for RNA transcription were amplified by PCR from the pIRES-NRAS-UTR-FL constructs with a forward primer [5'-TAA TAC GAC TCA CTA TAG GCT AGC CTC GAG AAA CGT CCC GTG T-3'] and reverse primer [5'-CGC GTG AAT TCT CGA TTA CAC GGC GAT CTT GCC GCC TTT C-3']. The PCR products were separated and purified by agarose electrophoresis, followed by gel extraction. RNAs were transcribed from the dsDNA templates using T7 RNA polymerase, and purified using an NAP-5 column to remove unincorporated NTPs. The resulting 5'UTR-NRAS-FL, 5'UTR-NRASmut1-FL, 5'UTRNRASmut2-FL, or 5'UTR-NRASmut3-FL were used as mRNA templates $(1 \mu \mathrm{g})$ in $20 \mu \mathrm{L}$ of cell-free protein expression mixture (RTS 100 Wheat Germ CECF Kit, 5 Prime, Inc.) with or without $10 \mu \mathrm{M}$ of RGB-1, for $1 \mathrm{~h}$ at $24^{\circ} \mathrm{C}$. Luciferase activity was evaluated using a Luciferase Assay kit (Promega) and an AB-2270 luminometer (ATTO).

Cell culture and western blot analysis of NRAS expression. MCF7 cells were maintained in medium A (Dulbecco's modified Eagle medium, supplemented with $100 \mathrm{units} / \mathrm{mL}$ penicillin, $100 \mu \mathrm{g} / \mathrm{mL}$ streptomycin sulfate, and $10 \%(\mathrm{v} / \mathrm{v})$ fetal bovine serum) at $37^{\circ} \mathrm{C}$ in a humidified $5 \% \mathrm{CO}_{2}$ incubator. On Day 0, MCF-7 cells were added to medium A in a 6-well plate at $3 \times 10^{6}$ cells per well. On Day 1, the cells were treated with DMSO (control) or a compound at various concentrations. Stock solutions of each compound in DMSO were added to give a 200-fold (v/v) dilution (1.0\% DMSO). After $48 \mathrm{~h}$ incubation, the cells were washed three times with cold PBS, and lysed with buffer A [20 mM Tris- $\mathrm{HCl}(\mathrm{pH} 7.5), 150 \mathrm{mM} \mathrm{NaCl}, 1 \%$ (v/v) Nonidet P-40, 0.1\% (w/v) sodium deoxycholate, and protease inhibitor cocktail (Nacalai Tesque, Inc.)]. The cell lysates were passed 10 times through a $25 \mathrm{G}$ needle and centrifuged at $4{ }^{\circ} \mathrm{C}$ for $10 \mathrm{~min}$. The 
supernatants were transferred to new tubes and mixed with 0.20 volume of $6 \times$ SDS sample buffer (Nacalai Tesque, Inc.). The samples were separated on a $15 \%$ SDS-PAGE gel, and blotted using antibodies against NRAS PA5-18888 (Thermo Fisher Scientific) or actin (IgG-AC-40, Abcam). The specific bands were visualized using enhanced chemiluminescence (ECL Prime Western Blotting Detection Reagent, GE Healthcare) on an ImageQuant LAS 500 (GE Healthcare).

RT-qPCR quantification of endogenous NRAS mRNA in MCF-7 cells. MCF-7 cells grown on a $10 \mathrm{~cm}$ dish were transfected with the pIRES vectors with the target gene. After $1 \mathrm{~d}$ of culture, the cells were harvested by scraping. Total RNA was isolated using ISOGEN (Nippon Gene Co., Ltd.), according to the manufacturer's protocol. First-strand cDNAs were reverse-transcribed from $100 \mathrm{ng}$ samples of the RNA, using an oligo (dT) primer and PrimeScript ${ }^{\mathrm{TM}}$ II $1^{\text {st }}$ strand cDNA Synthesis Kit (Takara Bio, Inc.), according to the manufacturer's protocol. The cDNAs were subjected to qPCR, using a pair of GAPDH primers to quantify GAPDH mRNA [5'-GCA CCG TCA AGG CTG AGA AC-3' and 5'-TGG TGA AGA CGC CAG TGG A-3'], and a pair of primers for amplification of NRAS DNA [5'- CCT ATA CAA TGT ATG TAA TTT GTT TCC -3' and 5'- CAA TGC ACC AAA GTT TTA CAA TAT TTG AAC-3'].

In vitro translation from TERRA-containing mRNA. The dsDNA for firefly luciferase (FL) was amplified by PCR using psiCHECK-2 (Promega) vector as a template, with a forward primer [5'-GCT GGT GTG AAA TGG CCG ATG CTA AGA ACA TTA AGA AGG GCC C -3'] and reverse primer [5'- CGC GTG AAT TCT CGA TTA CAC GGC GAT CTT GCC-3']. The dsDNAs for the TERRA, non-structured, and hairpin-stem 5'UTR were prepared by Klenow reaction, using synthetic oligonucleotides (Supplementary Table 1) with a primer [5'-ATG TTC TTA GCA TCG GCC ATC CAT GG-3']. The PCR products for 5'UTR (TERRA, non-structured, and hairpin-stem) and FL were connected by overlap extension PCR using a forward primer [5'- GAT CAA GCT TTA ATA CGA CTC ACT ATA GGG-3'] and reverse primer [5'-GAT CCT CGA GCC AAA CTC ATC AAT GTA TCT TAT CAT G-3']. The PCR products were subcloned into the Hind III and Xho I site in pCMV 3tag9 vector (Agilent Technologies). The linear dsDNA templates for RNA transcription were amplified by PCR using the pCMV 3tag9 constructs as templates, with a forward primer [5'- ATG TTC TTA GCA TCG GCC ATC CAT GG-3'] and reverse primer [5' GAT CCT CGA GCC AAA CTC ATC AAT GTA TCT TAT CAT G-3']. The PCR products were separated and purified by $2 \%$ agarose electrophoresis, followed by gel extraction. RNAs were transcribed from the dsDNA templates using T7 RNA polymerase, and purified using a NAP-5 column to remove unincorporated NTPs. The resulting 5'UTR-FLs, TERRA-containing, non-structured, and hairpin-stem, were used as mRNA templates $(1 \mu \mathrm{g})$ in $20 \mu \mathrm{L}$ of cell-free protein expression mixture (RTS 100 Wheat Germ CECF Kit, 5 Prime, Inc.), with or without $10 \mu \mathrm{M}$ of RGB-1, for $1 \mathrm{~h}$ at $24{ }^{\circ} \mathrm{C}$. Luciferase activity was evaluated using the Luciferase Assay kit (Promega) and an AB-2270 luminometer (ATTO).

Cell culture and reporter gene assay. HEK293 cells were maintained in medium A (Dulbecco's modified 
Eagle medium, supplemented with 100 units $/ \mathrm{mL}$ penicillin, $100 \mu \mathrm{g} / \mathrm{mL}$ streptomycin sulfate, and $10 \%(\mathrm{v} / \mathrm{v})$ fetal bovine serum) at $37{ }^{\circ} \mathrm{C}$ in a humidified $5 \% \mathrm{CO}_{2}$ incubator. The dsDNAs for TERRA-containing and non-structured 5'UTR-FL were amplified by PCR from pUC19-FL constructs (Supplementary Methods), with a forward primer [5'-CTA GCC TCG AGA ATT CAT CGG GTT AGG GTT AGG GTT AGG GTT AGT AGA CCG CGG TGG GCC GCC ACC ATG GCC GAT GCT AAG AAC-3'] or [5'-CTA GCC TCG AGA ATT CAT CAA ATT AAA ATT AAA ATT AAA ATT AAT AGA CCG CGG TGG GCC GCC ACC ATG GCC GAT GCT AAG AAC-3'], and a reverse primer [5'-CTC GAC GCG TGA ATT TTA CAC GGC GAT CTT GCC GCC TTT CTT AGC C-3']. The dsDNA for Renilla luciferase (RL) was amplified by PCR using psiCHECK-2 (Promega) as a template, with a forward primer [5'- CGA CCC GGG CGG CCG ATG GCT TCC AAG GTG TAC GAC CCC GAG C-3'] and reverse primer [5'-TAA AGG GAA GCG GCC TTA CTG CTC GTT CTT CAG CAC GCG CTC C-3']. The PCR products for the 5'UTR-FLs or RL were subcloned into EcoR I site or Not I site, in multicloning site A (MCS-A) or MCS-B of pIRES vector (Clontech Laboratories, Inc.), respectively. On Day 0, HEK293 cells were added to medium A in 96-well plates at $1.0 \times 10^{4}$ cells per well. On Day 1, the cells were transfected with pIRES vectors with the target gene, using FuGENE® HD transfection reagent (Promega), according to the manufacturer's protocol. On Day 2, the cells were treated with RGB-1. After $24 \mathrm{~h}$ incubation, the cells in each well were lysed by freezethaw with Reporter Lysis Buffer (Promega), and aliquots were used to measure activities of firefly and Renilla luciferase. Firefly luciferase activity was measured using the Steady-Glo® Luciferase Assay System (Promega), and Renilla luciferase activity was measured using the Renilla-Glo® (Promega). Firefly luciferase activity was normalized to Renilla luciferase activity.

\section{Elemental analysis.}

Liquid chromatography analysis was performed on Prominence UFLC system (Shimadzu, Kyoto, Japan). The sample was separated using a Shim-pack XR-ODS column ( $3 \mathrm{~mm} \mathrm{id} \times 50 \mathrm{~mm}, 2.2 \mu \mathrm{m}$, Shimadzu GLC). The separation and detection of sample were achieved at $0.700 \mathrm{ml} / \mathrm{min}$ flow rate using isocratic method (MeCN with $0.1 \%$ TFA: $\mathrm{H}_{2} \mathrm{O}$ with $0.1 \%$ TFA = $55: 45$ ) for 5.5 min with detection wavelength of $254 \mathrm{~nm}$ 


\section{Supplementary Figures}
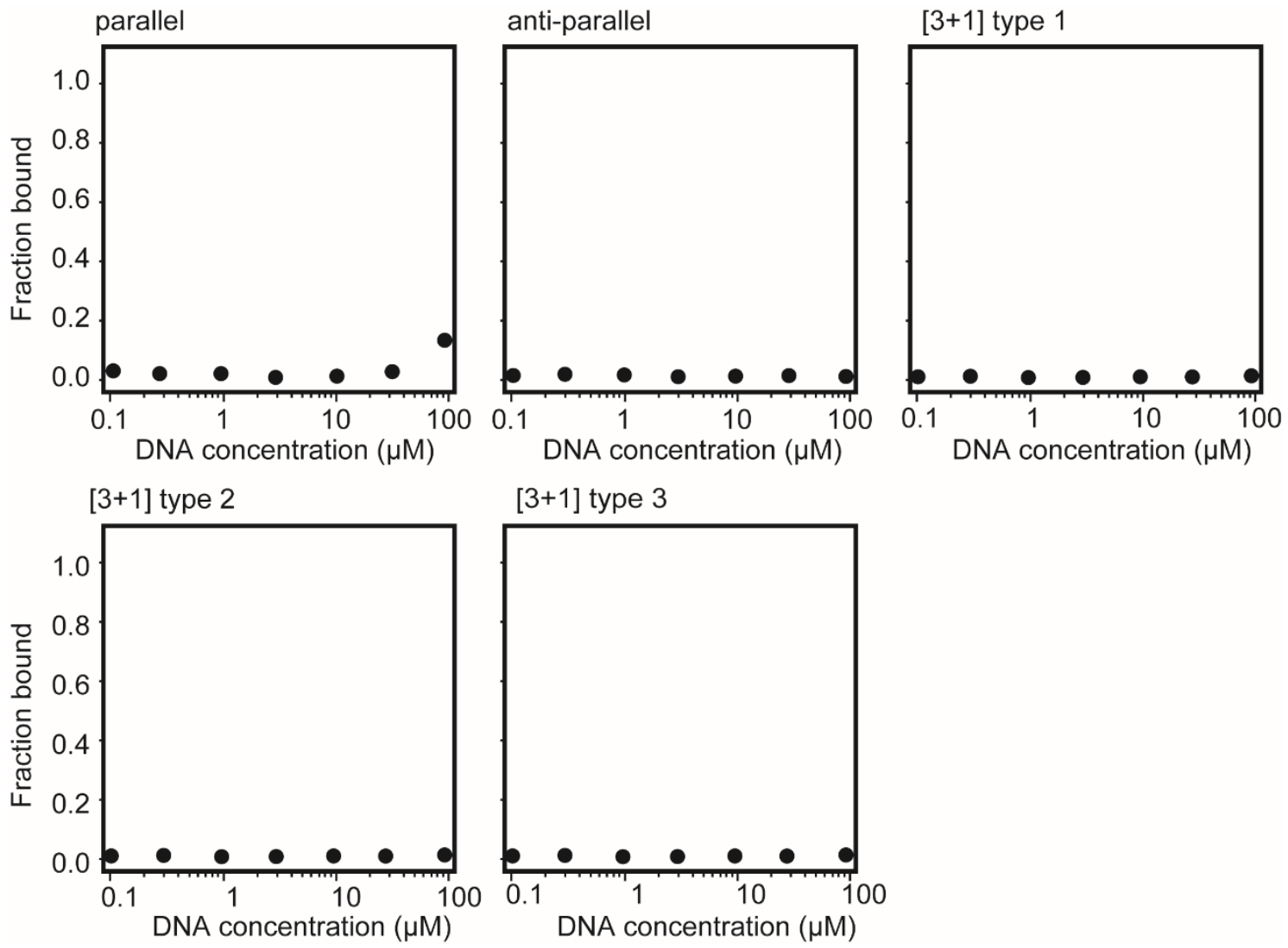

Figure S1 The direct interaction of RGB-1 with DNA G-quadruplexes. Semi-logarithmic plots showing the fraction of RGB-1 bound to each DNA G-quadruplex at room temperature. The sequences of each Gquadruplex are given in Table S1. The buffer was $10 \mathrm{mM}$ Tris- $\mathrm{HCl}$ (pH 7.6), containing $100 \mathrm{mM} \mathrm{KCl}$ or $\mathrm{NaCl}$. 
2 RNA G-quadruplex (TERRA)

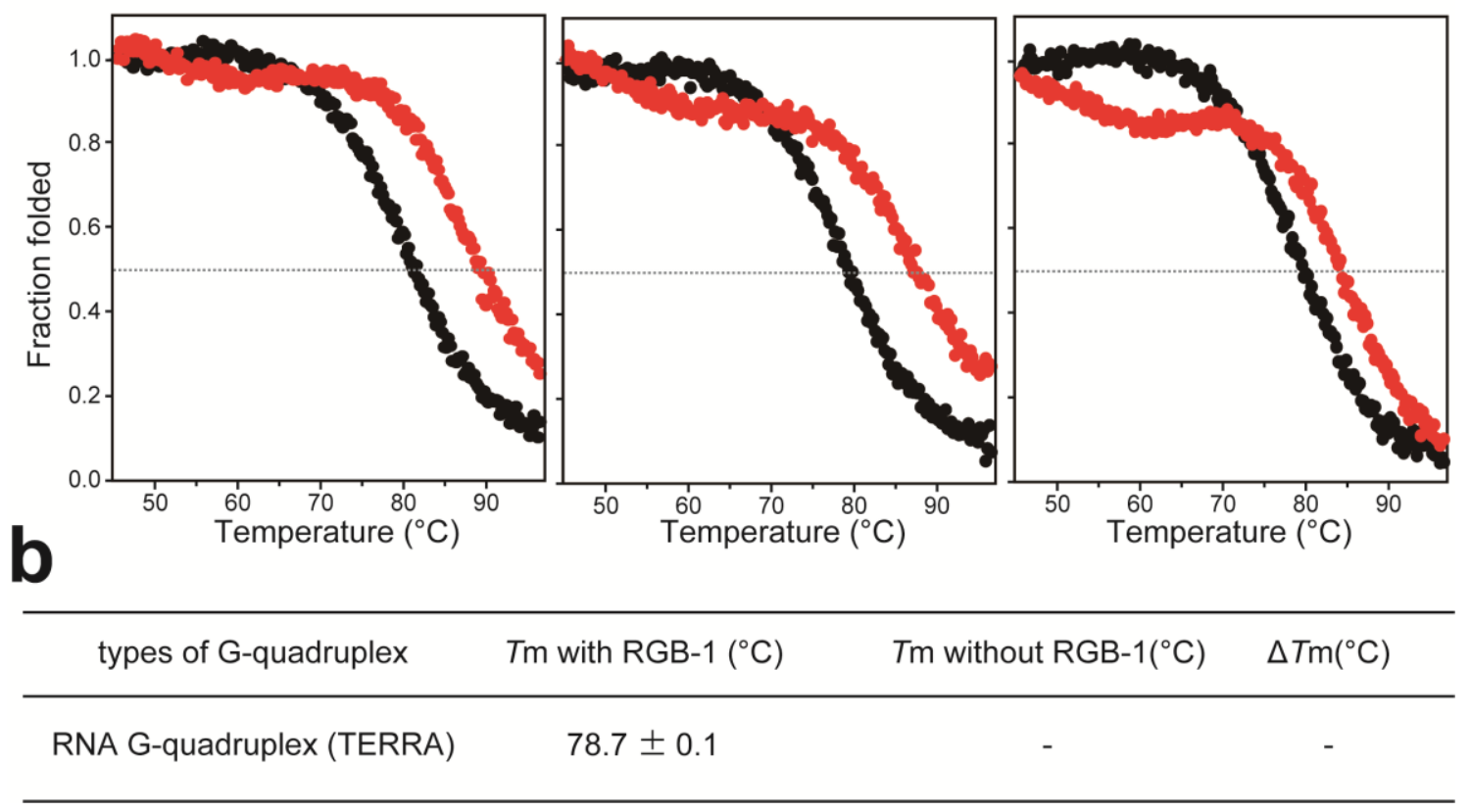

Figure S2. Measurement of melting temperatures $\left(T_{\mathrm{m}}\right)$ by CD spectroscopy of RNA G-quadruplexes, with (red circles) or without (black circles) RGB-1. (a) Effect of RGB-1 on melting temperature of TERRA. (b) $\Delta T_{\mathrm{m}}$ was determined by subtracting the $T_{\mathrm{m}}$ value with RGB-1 from the $T_{\mathrm{m}}$ value without RGB-1.

$\mathrm{S} 12$ 

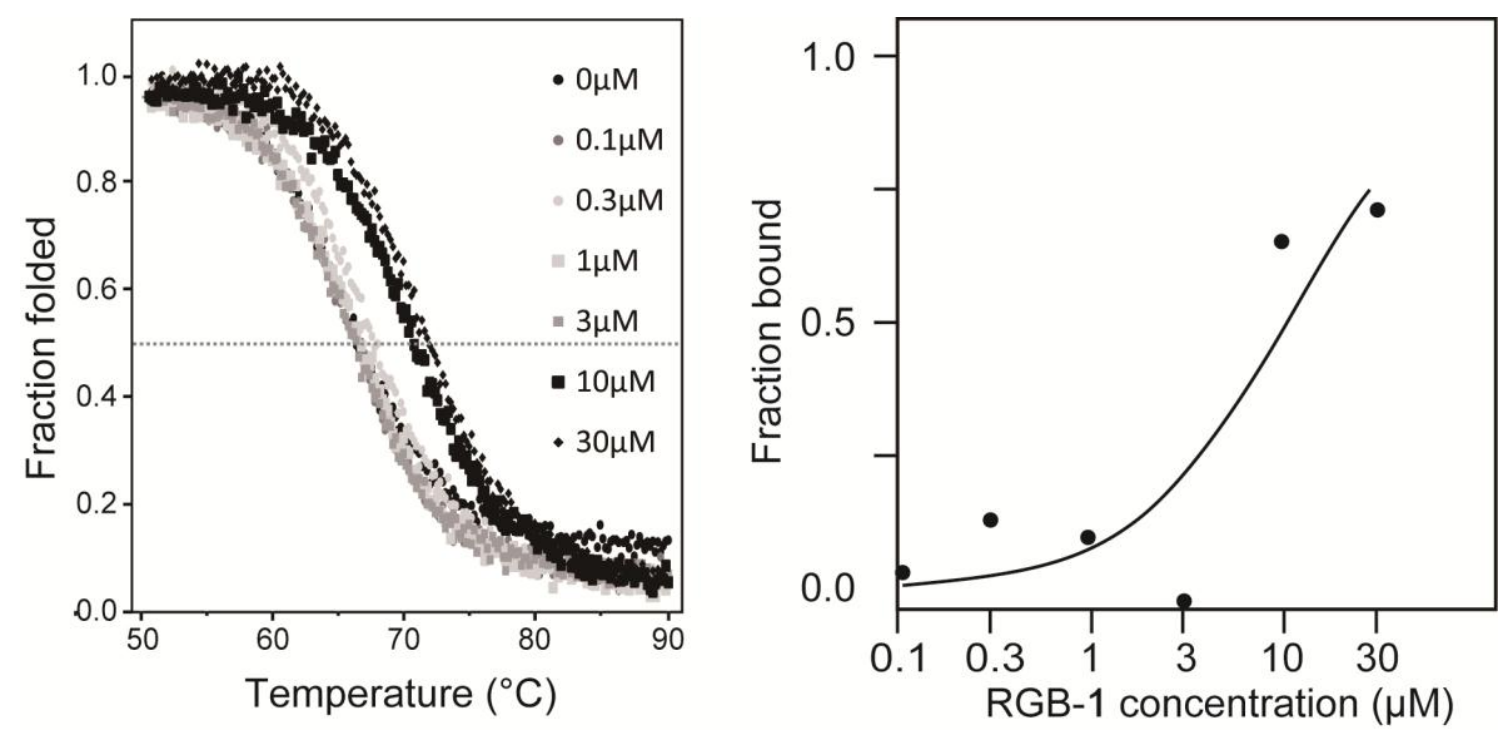

Figure S3 $K_{\mathrm{d}}$ determination of RGB-1-TERRA interaction by $T_{\mathrm{m}}$ measurements in $10 \mathrm{mM}$ Tris-HCl buffer (pH 7.6) containing $10 \mathrm{mM} \mathrm{KCl}$. $T_{\mathrm{m}}$ was measured by CD spectroscopy of TERRA with RGB-1 (0, 0.1, $0.3,1,3,10,30 \mu \mathrm{M})$. Semilogarithmic plots showing the fraction of RGB-1 bound to TERRA at each $T_{\mathrm{m}}$ temperature. 

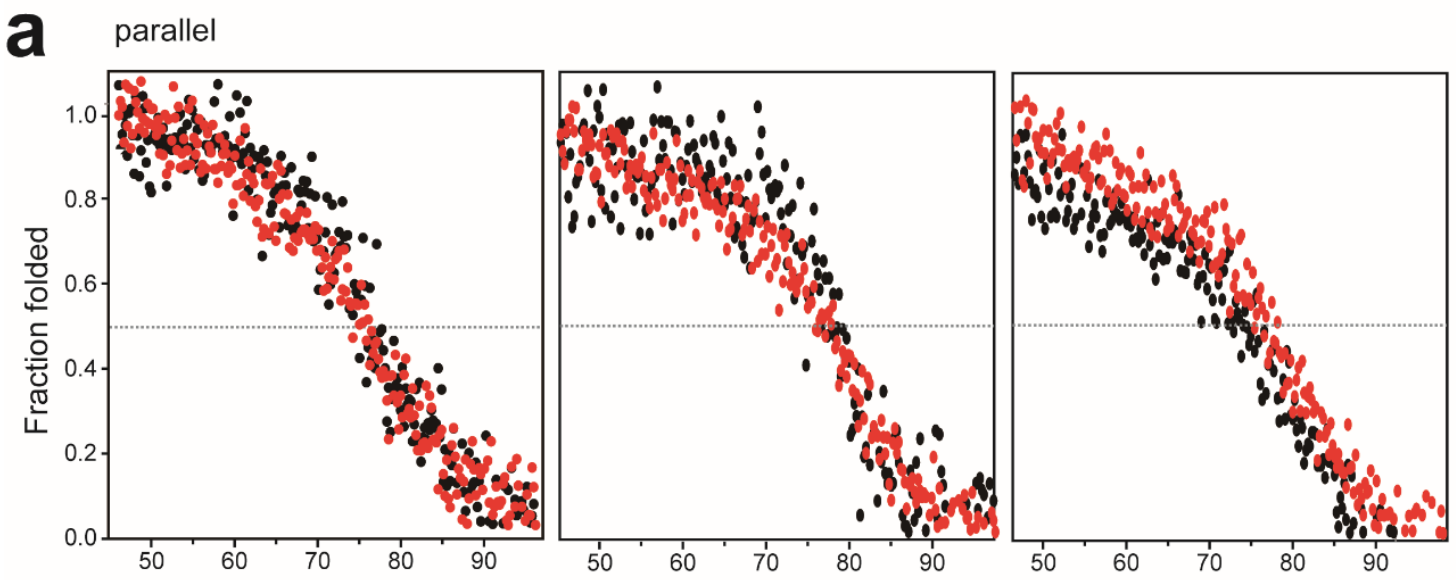

10 anti-parallel
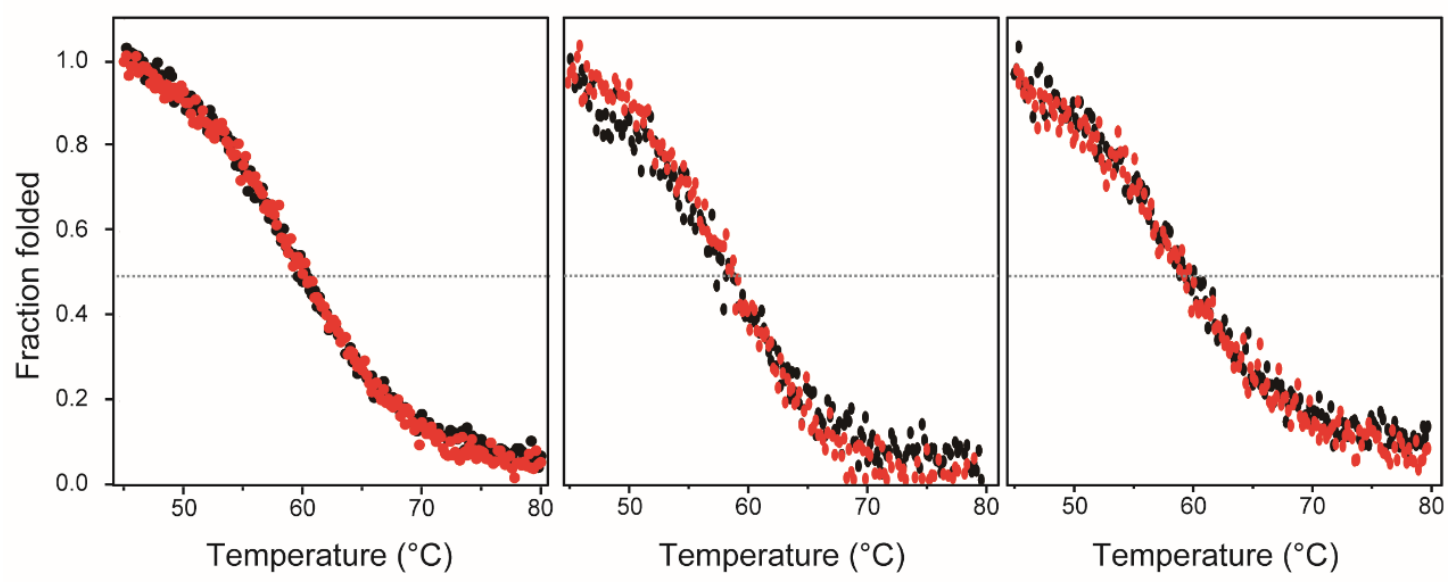

C

\begin{tabular}{cccc}
\hline types of G-quadruplex & Tm with RGB-1 $\left({ }^{\circ} \mathrm{C}\right)$ & Tm without RGB-1 $\left({ }^{\circ} \mathrm{C}\right)$ & $\Delta \operatorname{Tm}\left({ }^{\circ} \mathrm{C}\right)$ \\
\hline parallel & $77.8 \pm 1.2$ & $77.8 \pm 2.0$ & 0 \\
anti-parallel & $58.7 \pm 1.4$ & $58.8 \pm 0.7$ & 0.1 \\
\hline
\end{tabular}

Figure S4. Measurement of melting temperatures $\left(T_{\mathrm{m}}\right)$ by CD spectroscopy of DNA G-quadruplexes, with (red circles) or without (black circles) RGB-1. (a) Effect of RGB-1 on melting temperature of parallel type DNA G-quadruplexes. (b) anti-parallel type DNA G-quadruplexes. (c) $\Delta T_{\mathrm{m}}$ was determined by subtracting the $T_{\mathrm{m}}$ value with RGB-1 from the $T_{\mathrm{m}}$ value without RGB-1. 
a $[3+1]$ type 1

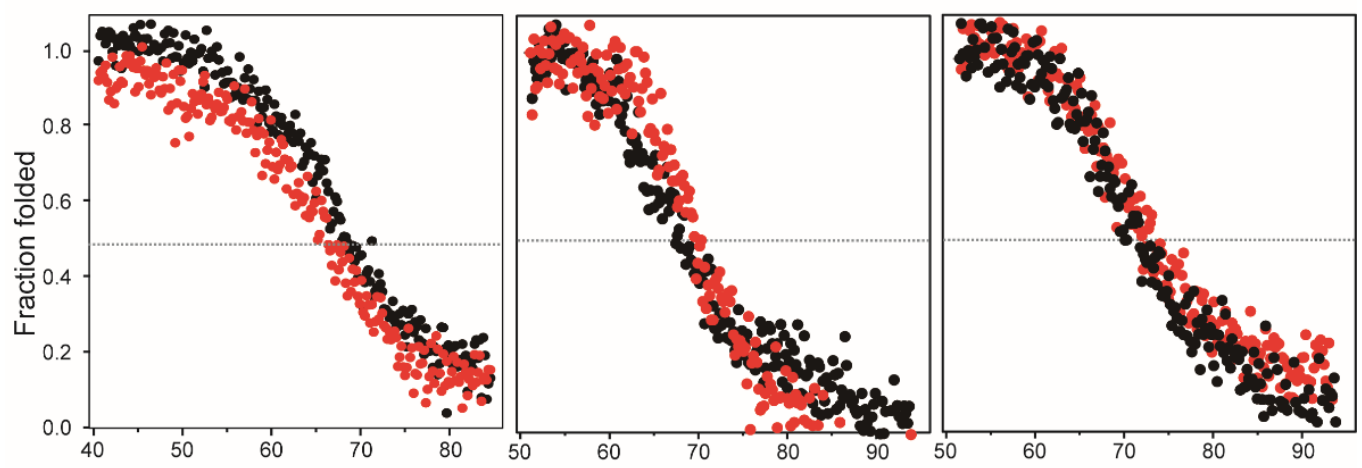

b [3+1] type 2

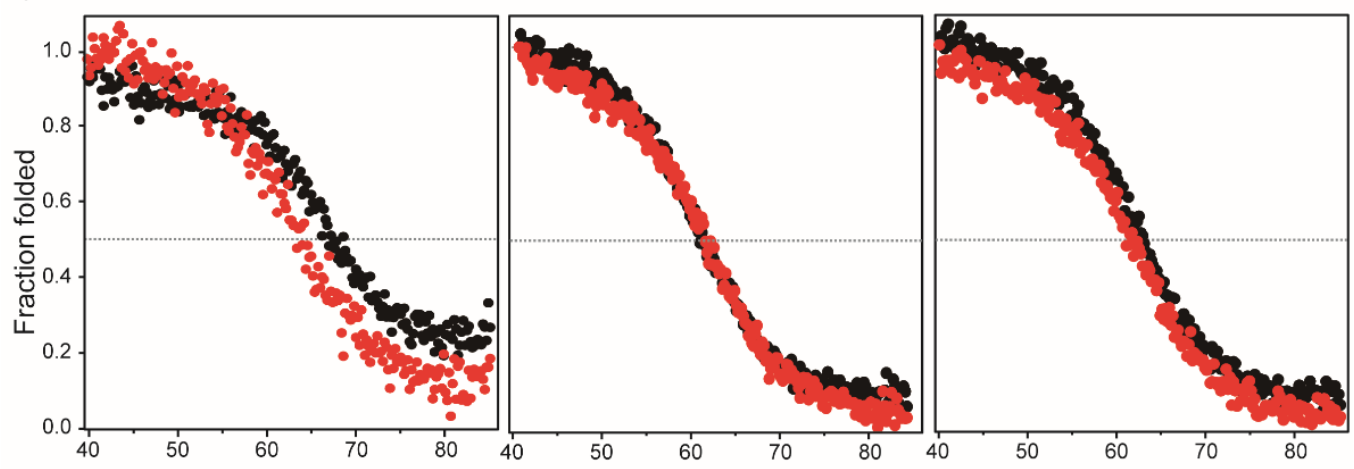

C $[3+1]$ type 3
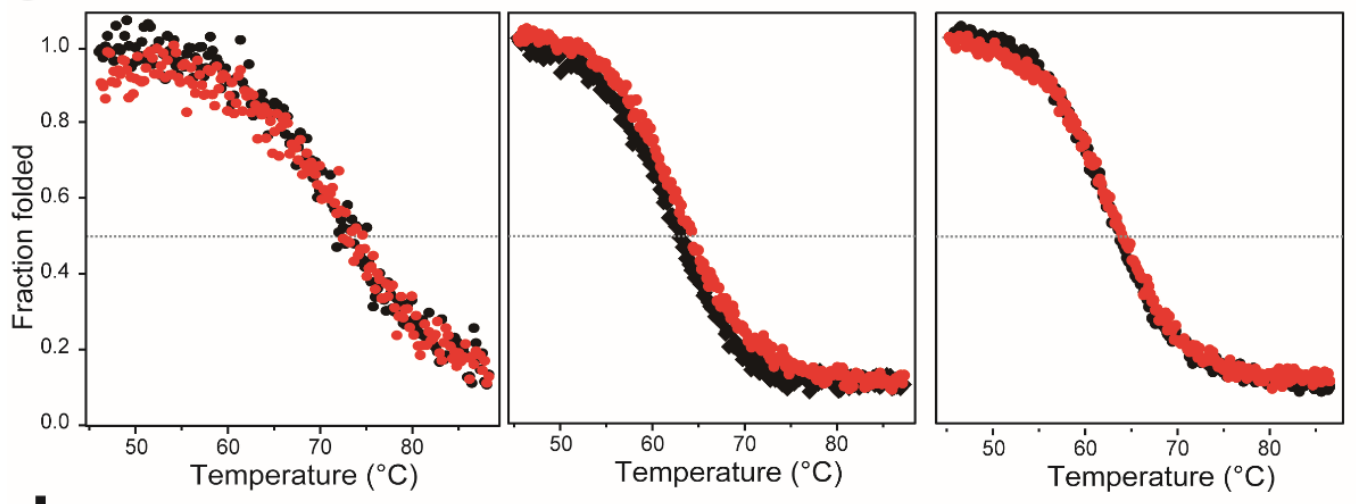

d

\begin{tabular}{cccc}
\hline types of G-quadruplex & $\mathrm{Tm}$ with RGB-1 $\left({ }^{\circ} \mathrm{C}\right)$ & $\mathrm{Tm}$ without RGB-1 $\left({ }^{\circ} \mathrm{C}\right)$ & $\Delta \mathrm{Tm}\left({ }^{\circ} \mathrm{C}\right)$ \\
\hline$[3+1]$ type 1 & $68 \pm 0.2$ & $68.4 \pm 1.4$ & 0.4 \\
{$[3+1]$ type 2 } & $63.1 \pm 0.8$ & $63.7 \pm 2.9$ & 0.6 \\
{$[3+1]$ type 3 } & $65.3 \pm 2.4$ & $64.8 \pm 1.9$ & -0.5
\end{tabular}

Figure S5. Measurement of melting temperatures $\left(T_{\mathrm{m}}\right)$ by CD spectroscopy of DNA G-quadruplexes, with (red circles) or without (black circles) RGB-1. (a) Effect of RGB-1 on melting temperature of [3+1 type1] DNA G-quadruplexes. (b) [3+1 type2] DNA G-quadruplexes. (c) [3+1 type3] DNA G-quadruplexes. (d) $\Delta T_{\mathrm{m}}$ was determined by subtracting the $T_{\mathrm{m}}$ value with RGB-1 from the $T_{\mathrm{m}}$ value without RGB-1. 

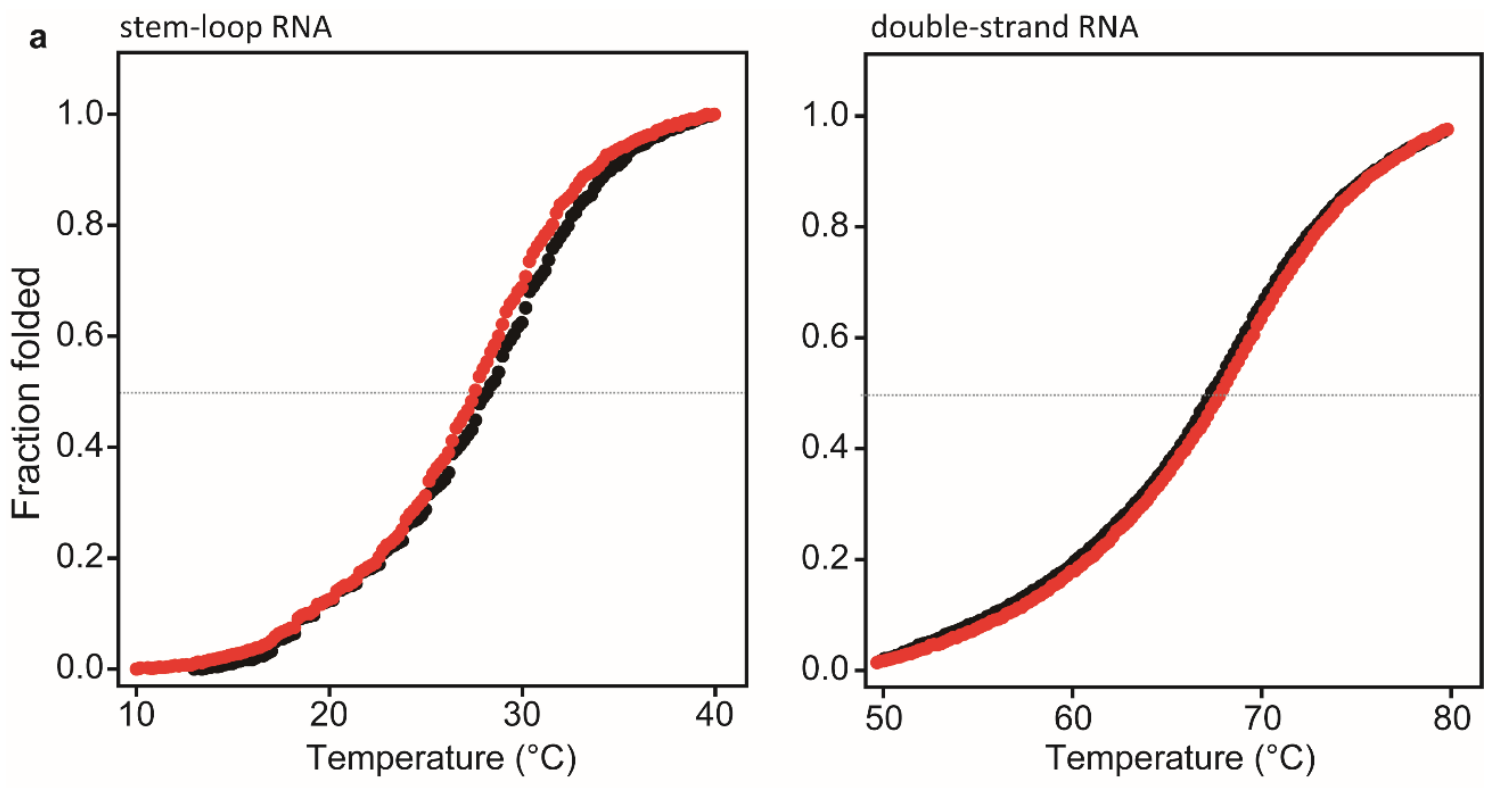

b

\begin{tabular}{lccc}
\hline types of G-quadruplex & $T \mathrm{~m}$ with RGB-1 $\left({ }^{\circ} \mathrm{C}\right)$ & $\operatorname{Tm}$ without RGB-1 $\left({ }^{\circ} \mathrm{C}\right)$ & $\Delta \operatorname{Tm}\left({ }^{\circ} \mathrm{C}\right)$ \\
\hline stem-loop RNA & 27 & 27 & 0 \\
double-strand RNA & 66 & 66 & 0 \\
\hline
\end{tabular}

Figure S6. (a) Measurement of melting temperatures $\left(T_{\mathrm{m}}\right)$ by UV absorbance of stem-loop and doublestrand RNA with (red circles) or without (black circles) RGB-1. (b) Effect of RGB-1 on melting temperature of stem-loop RNA and double-strand RNA. $\Delta T_{\mathrm{m}}$ was determined by subtracting the $T_{\mathrm{m}}$ value with RGB-1 from the $T_{\mathrm{m}}$ value without RGB-1. 

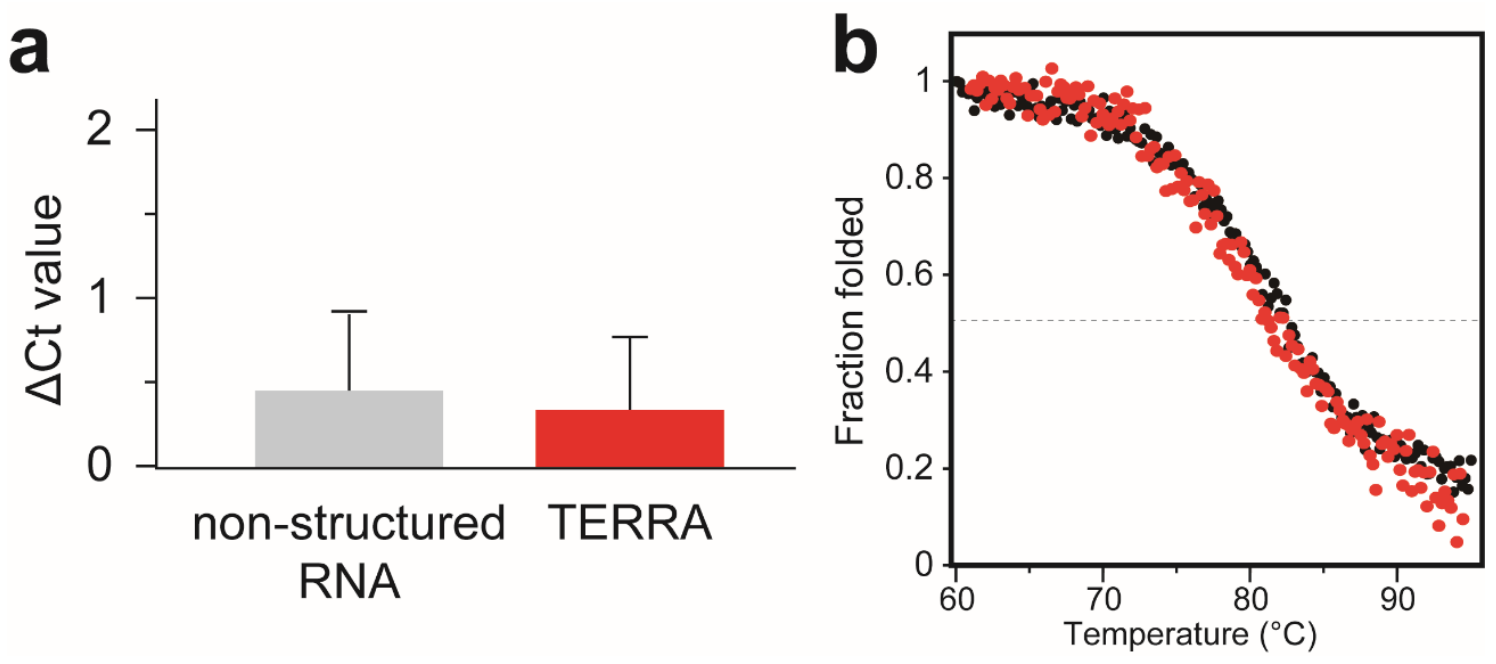

Figure S7. Effects of molecule 2 on RTase elongation and $T_{\mathrm{m}}$ of TERRA. (a) Molecule 2 showed no detectable effect on RTase elongation in both TERRA-containing RNA and non-structured RNA. $\Delta$ Ct was determined by subtracting the $\mathrm{Ct}$ value of qPCR with molecule 2 from the $\mathrm{Ct}$ value of qPCR without molecule 2. (b) Melting temperature ( $\left.T_{\mathrm{m}}\right)$ of TERRA with (red circles) or without (black circles) molecule 2. 
a

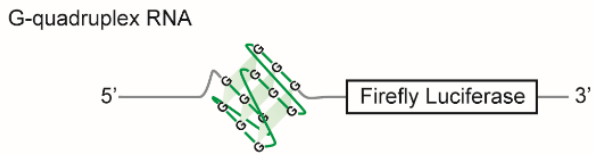

non-structured RNA

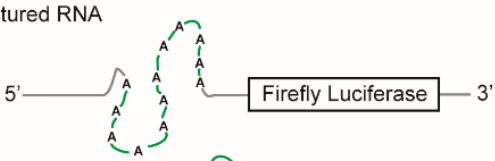

$5-c^{4} c^{c^{4}} \quad$ Firefly Luciferase 3

\begin{tabular}{cc}
\hline \multicolumn{1}{c}{ structures } & \multicolumn{2}{c}{ sequences } \\
\hline G-quadruplex RNA & $5^{\prime}-$ GGGUUAGGGUUAGGGUUAGGG - Luc. \\
non-structured RNA & 5 '- AAAUUAAAAUUAAAAUUAAAA - Luc. \\
hairpin-stem RNA & 5 '- CAGUACAGAUCUGUACUG - Luc.
\end{tabular}

C

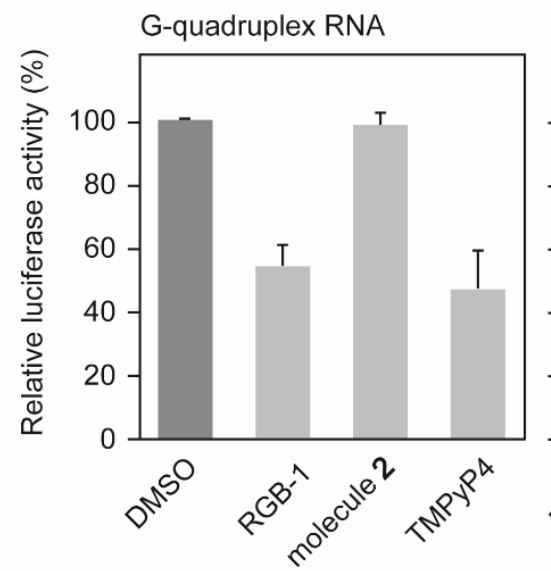

non-structured RNA

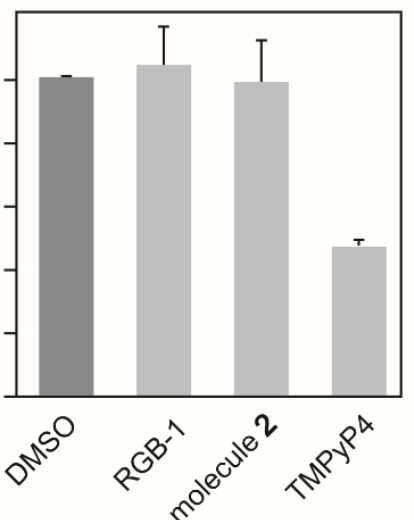

hairpin-stem RNA

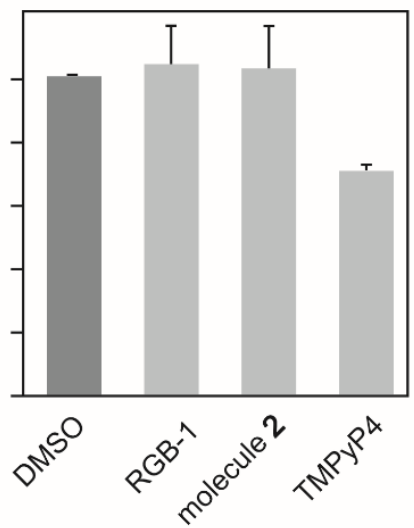

Figure S8. Effect of RGB-1 on translation from RNA G-quadruplex in vitro. (a) G-quadruplex, nonstructured, and hairpin-stem mRNAs encoding firefly luciferase were designed as models. (b) The nucleotide sequences of the 5'UTRs of the model mRNAs. Luc indicates the firefly luciferase gene. (c) Effect of RGB-1 on translation of reporter RNA in vitro. RGB-1 showed no detectable effect on translation from the non-structured and hairpin-stem RNA templates, but notably reduced translation from the TERRAcontaining RNA template. TMPyP4, a well-known G-quadruplex binder, non-specifically reduced translation from all model mRNAs. Molecule 2, a negative analog of RGB-1, had no detectable effect on translation from all model mRNAs. 
a

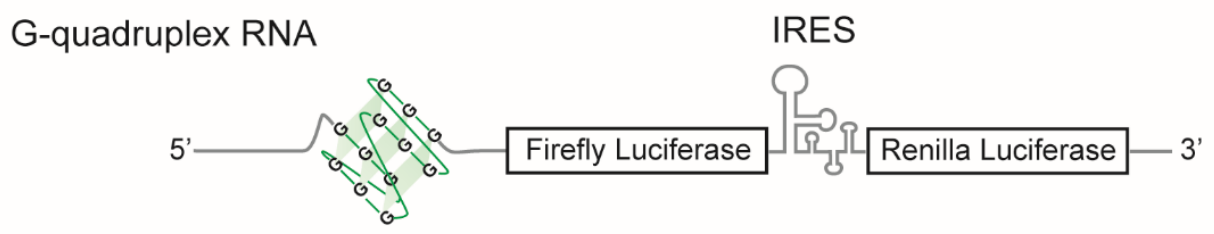

non-structured RNA

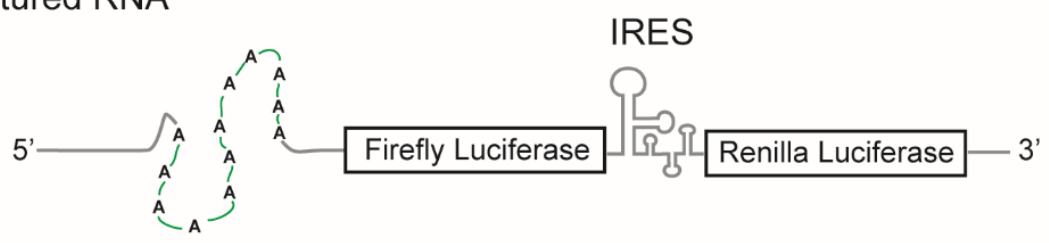

b

\begin{tabular}{cc}
\hline \multicolumn{1}{c}{ structures } \\
\hline G-quadruplex RNA & $5^{\prime}-$ GGGUUAGGGUUAAGGGUUAGGG - FL - IRES - RL $-3^{\prime}$ \\
non-structured RNA & $5^{\prime}-$ AAAUUAAAAUUAAAAUUAAAA - FL - IRES - RL - 3' \\
\hline
\end{tabular}
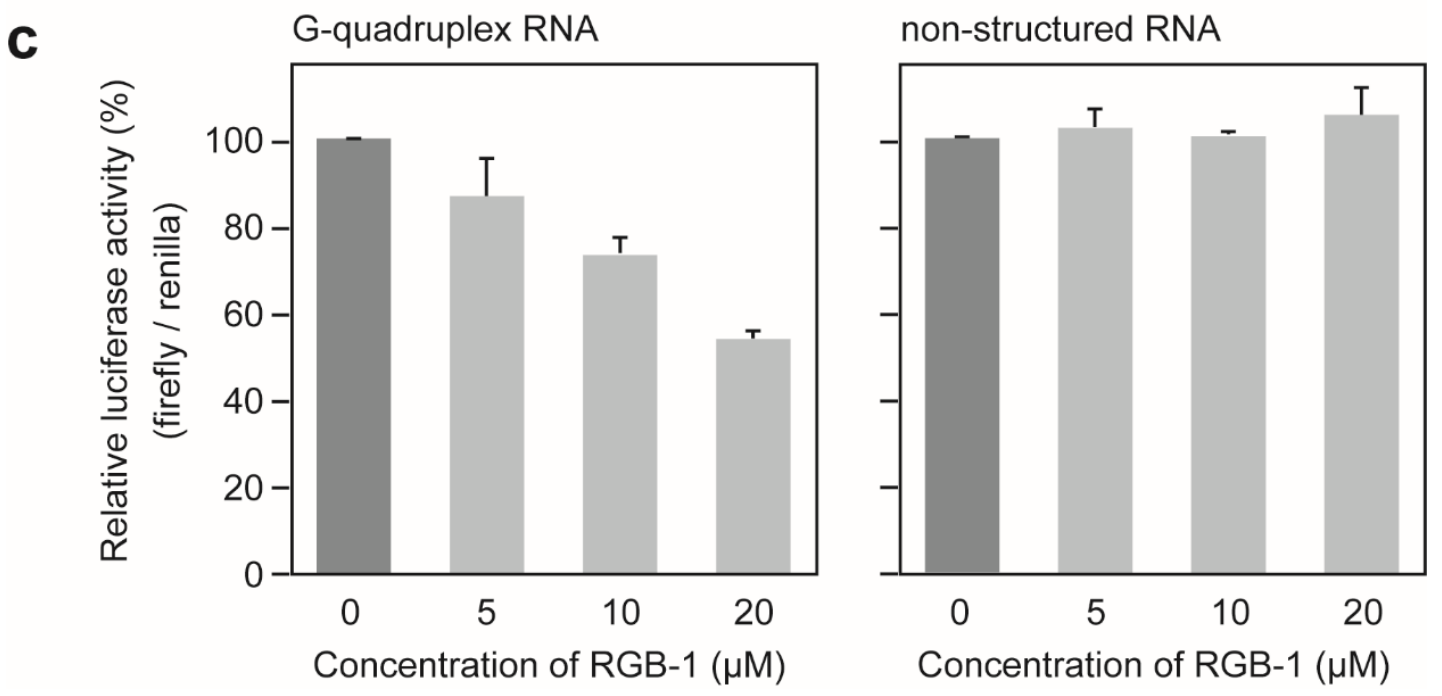

Figure S9. Effect of RGB-1 on translation from RNA G-quadruplex in HEK293 cells. (a) TERRA and nonstructured mRNAs encoding firefly luciferase (FL) were designed as models. Renilla luciferase (RL) was placed downstream of an internal ribosomal entry site (IRES) (b) The nucleotide sequences of the 5'UTRs. (c) RGB-1 showed no detectable effect on translation from the non-structured RNA templates, but notably reduced translation from the TERRA-containing RNA template. FL activity was normalized to RL activity. Error bars represent standard deviation for at least three independent experiments. 


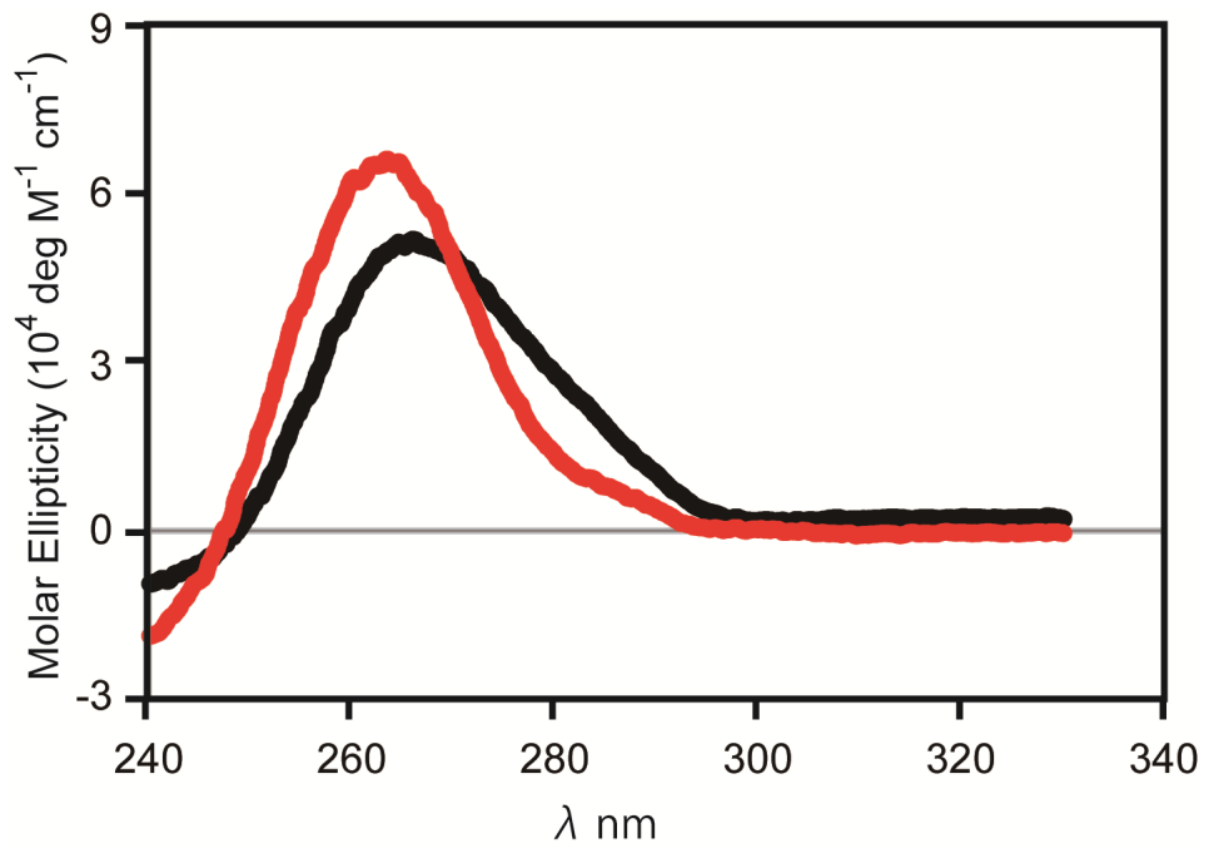

Figure S10. The CD spectra of oligo RNA (3) in Figure $3 f$ (red) and oligo RNA (4) in Figure $3 f$ (black) in $10 \mathrm{mM}$ Tris-HCl buffer (pH 7.6) containing $100 \mathrm{mM} \mathrm{KCl}$ at $10{ }^{\circ} \mathrm{C}$. 


\section{Supplementary Tables}

Table S1. DNA and RNA oligonucleotides for in vitro experiments. The guanine-triplet sequences are shown in bold letters. G-quadruplex forming sequences are underlined.

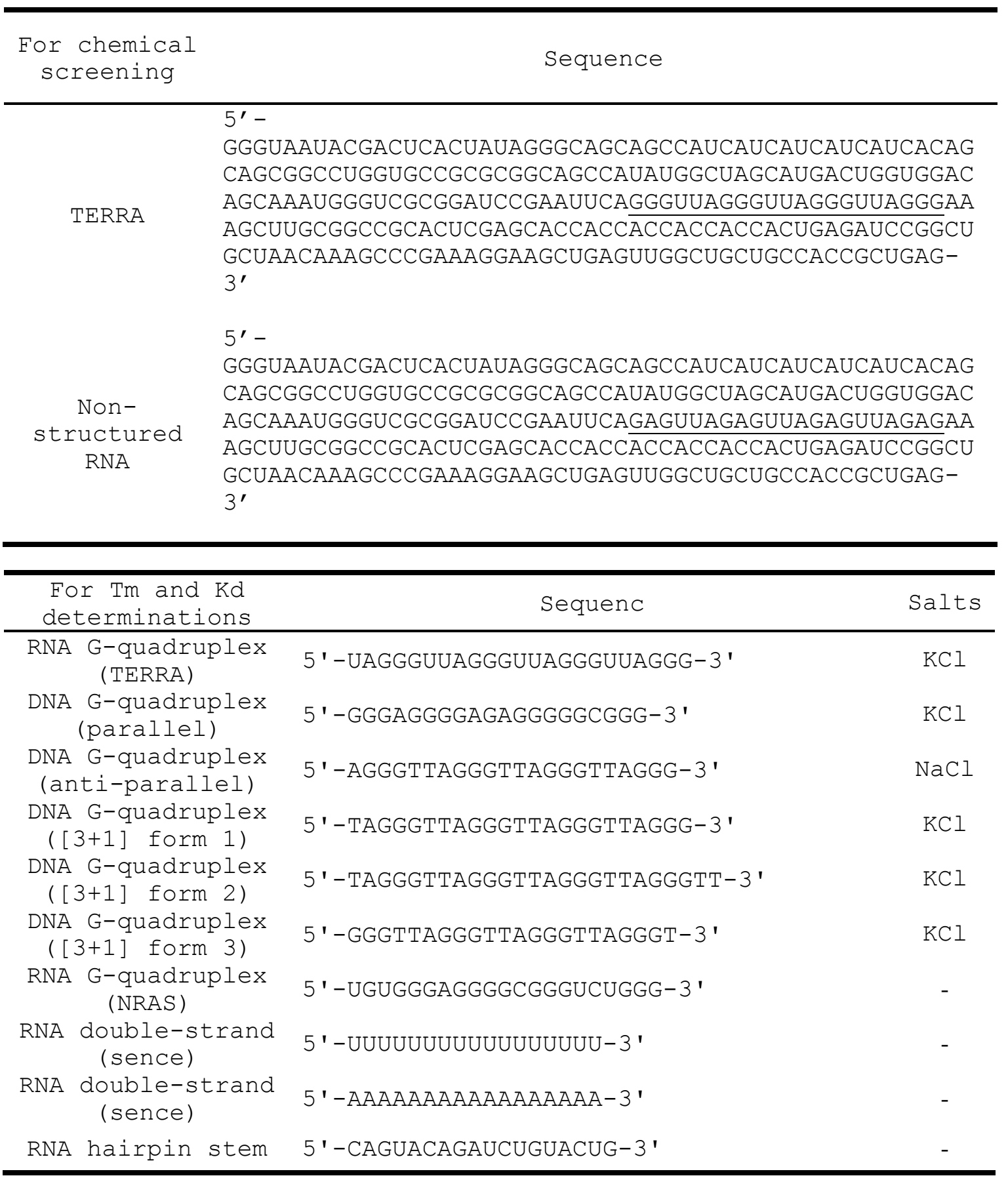


Table S2. 5'UTR RNA sequences used to examine translation in vitro. The start codons of firefly luciferase are shown in bold letters. Structure-forming sequences are underlined.

\begin{tabular}{|c|c|}
\hline Name & Sequence \\
\hline TERRA & $\begin{array}{l}5^{\prime}- \\
\text { CCUAAGCUUACAAAUACUCCCCCACAACAGCUUACAAUACUCCCCCA } \\
\text { CACAGCUUACAAAUACUCCCCCACAACGGGUUAGGGUUAGGGUUAGG } \\
\text { GAGCUUGUCGAACCAUGGAUG- }{ }^{\prime} \text { ' }\end{array}$ \\
\hline Non-structured & $\begin{array}{l}5^{\prime}- \\
\text { CCUAAGCUUACAAAUACUCCCCCACAACAGCUUACAAUACUCCCCCA } \\
\text { CACAGCUUACAAAUACUCCCCCACAACAAAUUAAAAUUAAAAUUAAA } \\
\underline{\text { AAGCUUGUCGAACCAUGGAUG- }{ }^{\prime}}\end{array}$ \\
\hline Hairpin-stem & $\begin{array}{l}5^{\prime}- \\
\text { CCUAAGCUUACAAAUACUCCCCCACAACAGCUUACAAUACUCCCCCA } \\
\text { CACAGCUUACAAAUACUCCCCCACAACCAGTACAGATCTGTACTGAG } \\
\text { CUUGUCGAACCAUGGAUG-3' }\end{array}$ \\
\hline NRAS wild-type & $\begin{array}{l}5^{\prime} \text { - } \\
\text { GAAACGUCCCGUGUGGGAGGGGCGGGUCUGGGUGCGGCCUGCCGCAU } \\
\text { GACUCGUGGUUCGGAGGCCCACGUGGCCGGGGCGGGGACUCAGGCGC } \\
\text { CUGGGGCGCCGACUGAUUACGUAGCGGGCGGGGCCGGAAGUGCCGCU } \\
\text { CCUUGGUGGGGGCUGUUCAUGGCGGUUCCGGGGUCUCCAACAUUUUU } \\
\text { CCCGGCUGUGGUCCUAAAUCUGUCCAAAGCAGAGGCAGUGGAGCUUG } \\
\text { AGGUUCUUGCUGGUGUGAACAGGUAUACAUAGUUGGAATG-3' }\end{array}$ \\
\hline NRAS mut 1 & $\begin{array}{l}5^{\prime} \text { - } \\
\text { GAAACGUCCCGUGUAAAAGGGGCGGGUCUGGGUGCGGCCUGCCGCAU } \\
\text { GACUCGUGGUUCGGAGGCCCACGUGGCCGGGGCGGGGACUCAGGCGC } \\
\text { CUGGGGCGCCGACUGAUUACGUAGCGGGCGGGGCCGGAAGUGCCGCU } \\
\text { CCUUGGUGGGGGCUGUUCAUGGCGGUUCCGGGGUCUCCAACAUUUUU } \\
\text { CCCGGCUGUGGUCCUAAAUCUGUCCAAAGCAGAGGCAGUGGAGCUUG } \\
\text { AGGUUCUUGCUGGUGUGAACAGGUAUACAUAGUUGGAATG-3' }\end{array}$ \\
\hline NRAS mut2 & $\begin{array}{l}5^{\prime} \text { - } \\
\text { GAAACGUCCCGUGUGGGAGGGGCGGGUCUGGGUGCGGCCUGCCGCAU } \\
\text { GACUCGUGGUUCGGAGGCCCACGUGGCCGGGGCGGGGACUCAGGCGC } \\
\text { CUGGGGCGCCGACUGAUUACGUAGCGGGCGGGGCCGGAAGUGCCGCU } \\
\text { CCUUGGUGGGGGCUGUUCAUGGCGGUUCCGGGGUCUCCAACAUUUUU } \\
\text { CCCGGCUGUGGUCCUAAAUCUGUCCAAAGCAGAGGCAGUGGAGCUUG } \\
\text { AGGUUCUUGCUGGUGUGAACAGGUAUACAUAGUUGGAATG-3' }\end{array}$ \\
\hline NRAS mut3 & $\begin{array}{l}5^{\prime}- \\
\text { GAAACGUCCCGUGUAAAAGGGGCGGGUCUGGGUGCGGCCUGCCGCAU } \\
\text { GACUCGUGGUUCGGAGGCCCACGUGGCCGGGGCGGGGACUCAGGCGC } \\
\text { CUGGGGCGCCGACUGAUUACGUAGCGGGCAAAACCGGAAGUGCCGCU } \\
\text { CCUUGGUGGGGGCUGUUCAUGGCGGUUCCGGGGUCUCCAACAUUUUU } \\
\text { CCCGGCUGUGGUCCUAAAUCUGUCCAAAGCAGAGGCAGUGGAGCUUG } \\
\text { AGGUUCUUGCUGGUGUGAACAGGUAUACAUAGUUGGAATG- }{ }^{\prime}\end{array}$ \\
\hline
\end{tabular}

